\title{
Professional Strategy for the School Administrator
}

\section{J. B. EDMONSON}

$\mathrm{W}$ directing forces so as to gain advantages in place, time, or conditions." The writer has found that administration is in part a succession of games, some of which may be won and others lost, tied, cancelled, or postponed. It is granted that strategy is only one aspect of educational administration and that no amount of attention to tactics will compensate for inadequate professional training, low professional objectives, or immaturity of character. Good strategy or generalship may, however, spell the difference between fair or high success in administration and between unhappy or happy experiences as a school administrator. Some of the observations ${ }^{1}$ of the writer relative to professional strategy or tactics may be summarized as follows:

\section{COMMUNITY RELATIONS}

1. It is poor strategy to "strut" one's potential authority, as many persons distrust a school administrator who seeks to advertise his power.

2. It is good strategy to know the controlling motives, the special interests, or the "touchy" points of leaders.

3. It is wise strategy to focus public attention on the significant achievements of the school, the pupils, and the staff rather than to seek personal credit.

4. No long record of successes in non-school organizations or activities will save the administrator who neglects the job for which he is employed.

5. An educational administrator should seek to avoid involvement in political disputes, community feuds, or church quarrels.

6. A shrewd administrator will seek to develop news policies calculated to hoid the confidence of the reporters of newspapers.

\section{STAFF RELATIONS}

7. A wise administrator will insure effective two-way communication with his staff and the patrons.

8. It is usually unwise for a newly appointed administrator to make immediate changes in many of the practices, policies, and rules of a predecessor.

1 To record your opinion on the value of the advice implied in a given statement, use the letters $\mathrm{A}, \mathrm{D}$, or $\mathrm{U}$ to mean Approve, Disagree, and Unimportant. Use the letter $\mathrm{X}$ to record "No opinion."

J. B. Edmonson was formerly the Dean of the School of Education at the University of Michigan, Ann Arbor, Michigan. 
9. In a large system, an administrator will find it is good strategy to combat the tendency of those in the several school buildings to consider that the headquarters staff decides everything without consultation with those in other buildings.

10. Except in an emergency, it is poor strategy to call staff meetings without adequate warning and careful planning.

11. It is good strategy to meet as many staff members as possible at places other than the central office.

12. A wise administrator will give associates the benefit of doubt and will seek ways of protecting them against their own weaknesses.

13. An expert administrator will avoid extending unwarranted recognition to any one or more cliques in the organization.

14. Staff members should not have their sense of security undermined by false rumors, hasty decisions, or administrative threats.

15. A far-sighted administrator will keep future plans for the schools before the staff in anticipation of possible rumors and crises.

16. A competent administrator will share credit with others, even to the point of giving undue recognition of associates.

17. A wise administrator will strive for teamwork and will usually use "we" and "our" rather than "I" and "mine" in discussing successes and problems.

18. The office staff should always be kept informed regarding the schedule of the administrator.

\section{OFFICE POLICIES}

19. Most callers are satisfied with an interview if treated with courtesy and allowed to talk for ten minutes.

20. All letters should be acknowledged, but most writers are satisfied if they receive a reply, even though it may not cover all issues raised.

21. It is poor tactics to spend time quarreling or disagreeing with people by correspondence or over the telephone.

22. An administrator should seek to avoid being placed in an unfavorable light by those members of the office staff who may treat callers with scant courtesty, release confidential information, or usurp authority.

\section{OPPOSITION AND CRITICISM}

23. An administrator should expect some criticism and opposition and should prepare himself accordingly, otherwise he may be caught "off base."

24. It is good strategy to plan for new developments and to hold the plans until openings occur to advance them without too much opposition. 
25. It is desirable strategy to resist the temptation to become discouraged or disgruntled because of the coolness, criticisms, or open opposition of associates.

26. An administrator should seek to develop a capacity to endure criticism and opposition by developing expert footwork, a tough skin, or a sustaining philosophy of administration. A combination of these is always the best preparation.

27. A skillful administrator will use humor or incidents to relieve tensions and strains in individual or group conferences.

28. An expert in strategy will anticipate problems with such care that a succession of costly crises for himself, his associates, the parents, the secretarial staff, and the pupils will be avoided.

29. An administrator should always remember that the Lord is the only one that treats plans, opinions, motives, and decisions as strictly confidential.

30. An administrator should not dance on the graves of enemies, as their friends may object to the noise.

31. A shrewd administrator will not boast about his strategy or tactics, as many persons are very suspicious of strategists except in team sports or military affairs.

\section{Who Are Most Likely to Drop Out of High School?}

$\mathrm{T}$ HIS was the question asked by Doron Warren in making a drop-out study of the class of 1952 at the Austin (Minn.) Junior-Senior High School. A total of 380 individuals was studied-136 boys and 132 girls who entered in grade VII; 59 boys and 53 girls who entered in grade IX (mostly from rural areas). Findings relate to an analysis of holding power of a 6-year high school enrolling about 2,200 pupils. Here are some things Warren found out: (1) pupils entering a 6-year high school in grade VII show slightly greater stay-in-school power than those entering grade IX; (2) pupils entering in grade IX who drop out tend to withdraw during the year in which they cntcr; (3) though nure pupils of lesser scholastic ability are remaining to be graduated, intelligence quotients are factors affecting holding power; (4) there appears to be a connection between poor reading ability and a pupil's tendency to drop out; (5) a pupil with a poor attendance record is much more likely to drop out than one with a satisfactory attendance record; (6) participation in extraclass activities seems to be influential in holding pupils in high school; (7) the financial condition of the pupil (need for working part-time outside of school) does not appear to be a chief factor in causing drop-outs; and (8) youth who withdraw from school frequently come from homes of unskilled workers and farmers. A 32-page study contains 17 tables as well as suggestions for corrective actions to increase holding power. For idditional information, write to Assistant Principal Doron Warren. 